表 7 カーボンブラックの生産・出荷量 ${ }^{4)}$ (単位: $\mathrm{t}$ )

\begin{tabular}{c|r|r}
\hline 年 & 生産量 & 出荷量 \\
\hline 2005 年 & 805,179 & 807,330 \\
\hline 2006 年 & 827,468 & 826,980 \\
\hline 2007 年 & 834,526 & 839,056 \\
\hline 前年詨比 (\%) & 101 & 101 \\
\hline
\end{tabular}

表 8 炭素繊維の生産・出荷量1)

\begin{tabular}{c|c|c}
\hline 年 & 生産量 & 出荷量 \\
\hline 2005 年 & 10,566 & 7,810 \\
\hline 2006 年 & 10,869 & 7,981 \\
\hline 2007 年 & 13,166 & 9,231 \\
\hline 前年対比 $(\%)$ & 121 & 116 \\
\hline
\end{tabular}

電の風車ブレード, 自動車など輸送機器及び一般産業機械向 けで大きく需要が伸びている。さらに近年の地球環境問題 · LCA・リサイクルへの対応や製造物責任法（PL 法）などに対 し，国内で調査研究が始まった。大手 3 社の再生炭素繊維に 関する技術提携のほか，炭素繊維協会がリサイクルに関する 実証実験を2008年から開始することを発表しており，今後の 動きが注目される。ピッチ系は，加工・成型品の強化により 高付加価值化を図る動きが国内各社に見られた。表 8 に炭素 繊維の生産・出荷量を示す。

\section{7. ナノカーボン}

カーボンナノチューブ (CNT) の製造に関し, 国内にて単 層CNTの安価な大量合成法が確立されつつあるのに加え, 高 品質・高純度化が進められている。また複合材料を主とした 産業化に向けた動きが活発となってきた。一方，海外メーカー によるアジア市場参入の動きが見られつつある。例えば英 トーマス・スワン社は日本で当面半導体業界向けに単層 CNT の売り达みに力を入れる様子であり，また独バイエルマテリ アルサイエンス社は多層CNTの増産及び日本国内への売込み を今後行う旨を発表している。

フラーレンは，国内で先導的な位置づけにあるフロンティ アカーボン社が関連事業を加速させる旨の発表を行い, フ ラーレンの高純度化や化学修飾等によるフラーレン製品の多 様化を進めている。2008年にはフラーレン及び誘導体の試薬 会社を通じた販売を開始するとのことである。フラーレンの 産業化の可能性としては，現在のところ各種樹脂との複合化， 電子材料用途, 有機デバイス用途が挙げられるが，未だしば らくは模索が続く模様である。

\section{文 献：References}

1）経済産業省，宰業·建材統計年報 2 2) 炭素協会資料 3）日本貿易 統計 4）経済産業省, 化学工業統計年報

\section{8 石炭灰の利用}

はじめに

石炭は埋蔵量が豊富でかつ地域偏在性が少なく，また他の 化石燃料と比較して単位発熱量（カロリー）当りの単価が安 いことから，我が国では今後も重要なエネルギー源として位 置付けられている。石炭を安定的に利用していくためには，石 炭の欠点である二酸化炭素排出量等に対して環境に調和した 形で利用していくことや，さらに燃焼の副産物である石炭灰 の有効利用が重要である。以下に最新のデー夕に基づく我が 国の石炭灰の発生・利用状況と利用技術動向の概要について 紹介する。

\section{1. 石炭灰の発生量と利用量}

日本における2006年度の石炭灰の発生量は合計 1,097 万で あった。産業別に見ると電気事業で 810 万t，一般産業で 287 万 $\mathrm{t}$ 発生しており，前年に対して各々約 23 万 $\mathrm{t}$ 減小，約 5 万 $\mathrm{t}$ 増加している。電気事業, 一般産業の発生比率は $2.8: 1$ で あった。有効利用量は電気事業で781万t，一般産業で 284 万 $\mathrm{t}$ で合計 1,065 万 $\mathrm{t}$ と 1 千万 $\mathrm{t}$ を超過している。石炭灰の発生量 と有効利用量の推移を図 1 に, 電気事業と一般産業別の石炭 灰発生量の推移を図 2 に示す。

また，図 3 に石炭灰有効利用率の推移を示す。

有効利用率は近年一貫して向上しており，2006年度は電気 事業 96\%，一般産業 99\%，全体で 97\%となっている。

\section{2. 石炭灰の有効利用分野}

2006年度における石炭灰の有効利用の分野別内訳を表 1 に 示す。

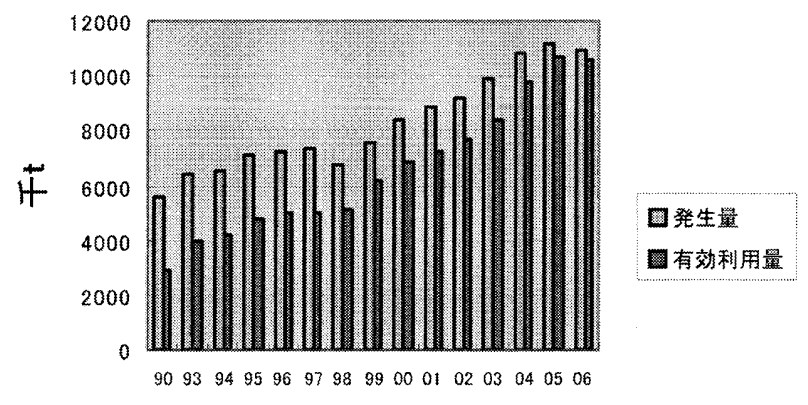

図 1 石炭灰の発生量・有効利用量

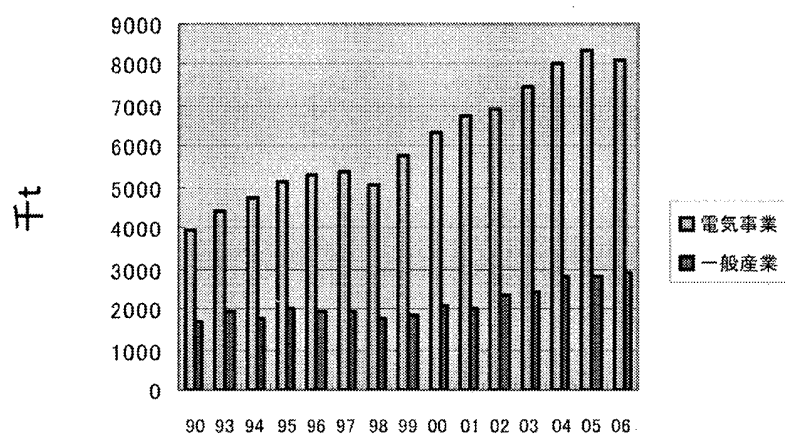

図 2 電気事業と一般産業の石炭灰発生量 


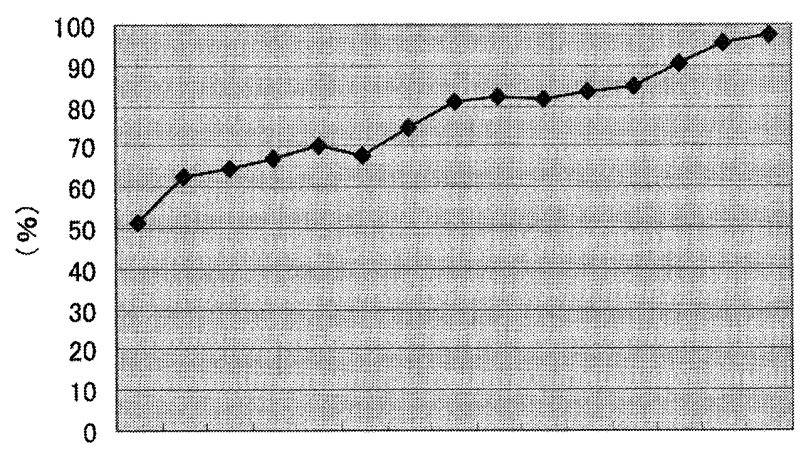

$\begin{array}{lllllllllllllll}90 & 93 & 94 & 95 & 96 & 97 & 98 & 99 & 00 & 01 & 02 & 03 & 04 & 05 & 06\end{array}$ 図 3 石炭灰の有効利用率の推移

また，分野毎の有効利用の割合を図 4 に示す。

セメント分野の有効利用量が全体の 7 割程度を占め, この 内セメント原料としての利用が大部分を占めている。これは, セメントの製造には本来セメント $1 \mathrm{t}$ 当たり $200 \mathrm{~kg}$ 程度の粘 土を必要とするが，その代替材として石炭灰を使用するもの である。石炭灰の発生量が今後増加傾向となった場合, セx ントの生産量は横ばいか若干減少傾向にあるため，近い将来 セメント原料として，受入れの余裕が無くなってくることが 予想される。

土木分野では，主に道路路盤材，地盤改良材，炭坑充填材 として利用されており，比率は $13 \%$ 程度であるが，前年に比 べて道路路盤材利用が $2 \%$ ぼ増えており，大量の有効利用 という観点から，この分野での利用の拡大が望まれる。

建設分野では，建材ボードの原料として安定的に利用され ており, 軽量骨材としては, 現在密度 $1.35 \mathrm{~g} / \mathrm{cm}^{3}$ 程度のものが

表 1 石炭灰の有効利用の分野別内訳 ${ }^{11}$

\begin{tabular}{|c|c|c|c|}
\hline 分野 & 項 目 & 利用量 & 比率 (\%) \\
\hline \multirow{4}{*}{$\begin{array}{c}\text { セメント } \\
\text { 分野 }\end{array}$} & セメント原材料 & 6,885 & 64.61 \\
\hline & セメント混合材 & 277 & 2.60 \\
\hline & コンクリート混和材 & 109 & 1.02 \\
\hline & 計 & 7,271 & 68.23 \\
\hline \multirow[t]{7}{*}{ 土木分野 } & 地盤改良材 & 311 & 2.92 \\
\hline & 土木工事用 & 541 & 5.08 \\
\hline & 電力工事用 & 46 & 0.43 \\
\hline & 道路路盤材 & 298 & 2.80 \\
\hline & アスファルト・フィラー材 & 10 & 0.09 \\
\hline & 炭坑充填用 & 203 & 1.90 \\
\hline & 計 & 1,409 & 13.22 \\
\hline \multirow[t]{4}{*}{ 建築分野 } & 建材ボード & 365 & 3.42 \\
\hline & 人工軽量骨材 & 0 & 0.00 \\
\hline & コンクリート 2 次製品 & 30 & 0.28 \\
\hline & 計 & 395 & 3.71 \\
\hline \multirow{3}{*}{$\begin{array}{c}\text { 農林水産 } \\
\text { 分野 }\end{array}$} & 肥料 & 72 & 0.68 \\
\hline & 土潩改良材 & 89 & 0.84 \\
\hline & 計 & 161 & 1.51 \\
\hline \multirow{5}{*}{ その他 } & 下水污水処理材 & 3 & 0.03 \\
\hline & 製鉄用 & 12 & 0.11 \\
\hline & その他 & 1,406 & 13.19 \\
\hline & 計 & 1,421 & 13.33 \\
\hline & 有効利用合計 & 10,657 & 100.00 \\
\hline
\end{tabular}

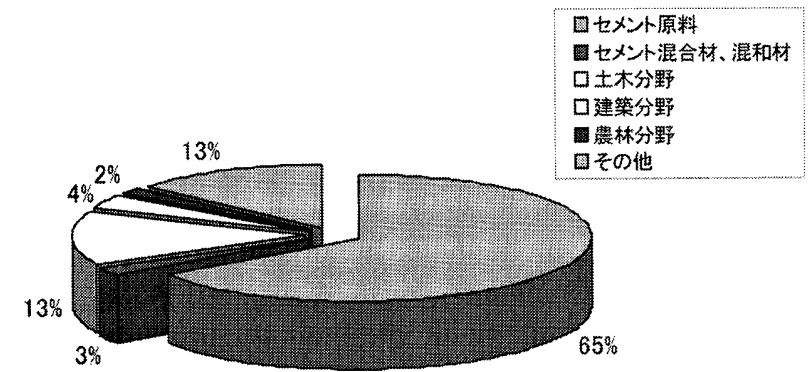

図 4 利用分野内訳

試験的に製造・販売されているが，量的には少量にとどまっ ている。

農林水産分野では, けい酸カリ肥料の原料として石炭灰が 利用され，少量ではあるが安定した需要がある。

以下に各分野の利用技術の概要について紹介する。

\section{3. 各分野での利用技術}

(1)セメント混合材，コンクリート混和材

フライアッシュを利用したコンクリートには，長期強度の 増進, 乾燥収縮の減少, アルカリ骨材反応の抑制等, 種々の 特長があり，またフライアッシュがそのままセメントを代替 する製品として利用できるので, 省エネルギー・省資源の観 点からも価值の高い利用法である。コンクリートに用いるフ ライアッシュについては, JIS A6201でその化学成分及び物理 的性質が規定されている。EUでは同様のフライアッシュ規格 が環境との共存という観点から見直されている。(BS EN 4501,2:2005）この分野での有効利用量は年間 38 万 $\mathrm{t}$ 程度である が，潜在的な有效利用量が見込まれる分野である。

\section{(2) 土木分野}

土木分野では，地盤改良材，道路路盤材，炭鉱充填材等に 利用されており，この分野の利用量は年間141万程度である。

\section{a. 地盤材, 地盤改良材}

利用方法としては，セメント等の安定材を添加したスラ リーを充填する方法, 造粒する方法, 軟弱な建設発生土等を フライアッシュにより改質する方法，フライアッシュ $(\mathrm{F})$ と 石膏 $(\mathrm{G})$ とセメント（C) を混合して地艎改良を行う，FGC 工法等がある。

\section{b. 路盤材}

路盤材としては，ポゾテック（フライアッシュ十脱硫石高 十石灰), ナルトン (流動床灰十水, 蒸気養生) 等がある。路 盤材用の砕石は年間 1 億以上と十分大きな需要がある分野で あり，市場で受け入れられる価格での供給，地方自治体への $\mathrm{PR}$ 等により普及を図ることが期待される。

\section{(3) 建築分野}

a. 建材ボード

建築用内外壁材，屋根瓦，陶器等に石炭灰が利用されてお 
り，利用量は 36 万 $\mathrm{t}$ 程度である。

\section{b. 人工骨材}

石炭灰を用いた高強度人工骨材の開発が行われ，土木学会 からは設計・施工指針案が発行されている ${ }^{2\rangle}$ 。

四国地方では海砂に代わる細骨材対策として，細骨材の一 部をフライアッシュで置換する方法の検討が進められ，「フラ イアッシュを細骨材補充混和材として用いたコンクリートの 施工指針 (案)」が制定されている3)。

\section{（4）農林・水産分野}

a. 肥 料

石炭灰に含まれる難溶性の珪酸を活用した珪酸加里肥料が 年間 7 千 $\mathrm{t}$ 程度生産されている。

\section{b. 人工魚礁材}

石炭灰を大量に利用した固化ブロックを海底に沈積し，人 工海底山脈を増築することにより人工的な湧昇流を発生させ，
漁場を形成する技術が研究開発されている4)。

(5) その他

石炭灰の高付加価値利用の一つとして，石炭灰から人工ゼ オライトを製造する利用法がある。人工ゼオライトは, 吸着, イオン交換，触媒等の機能を持っており，土壤改良材，脱臭 剤, 水質浄化剂等としての利用が期待できる。現在，4ヶ所 で製造能力 $2,000 \sim 3,000 \mathrm{t} /$ 年程度の製造プラントが商業運転 を行っている。

\section{文 献：Reference}

1）(財) 石炭エネルギーセンター, 全国石炭灰実態調査報告書(平成 18 年 度実績), 平成 20 年 3 月 2) 土木学会, 高強度フライアッシュ人工骨材 を用いたコンクリートの設計・施工指針(案), 平成 13 年 7 月 $\quad 3 ＼mathrm{~ 河 野 ~}$ 清, 石炭灰フライアッシュの細骨材補充充填材としての使用, 石炭灰有効利 用シンポジウム講演集 (2003.12）４）日本フライアッシュ協会ホームペー ジフフライアッシュの用途，平成 20 年 4 月

\section{3. 天然ガス}

\section{1 天然ガス資源開発の動向}

\section{1 .1 国産天然ガス}

\section{1. 生産動向ほか}

平成 18 年度におけるわが国の天然ガスの生産量は，34 億 800 万 $\mathrm{m}^{3}$ と対前年度比 $8.5 \%$ の増加を記録した。特に新潟県が $12.2 \%$, 北海道が $9.5 \%$ 增と生産量の増大が継続し, 全体的に みればガス田ガス（構造性ガス十水溶性ガス）の増産が毫引 カとなっているのが判る。
県別に見ると新潟県がトップで, 約 22.7 億 $\mathrm{m}^{3}, 2$ 位が千葉 県の約 4.7 億 $\mathrm{m}^{3}, 3$ 位が北海道で約 4.5 億 $\mathrm{m}^{3}, 4$ 位は福島県 の約 1.7 億 $\mathrm{m}^{3}$ となっている。以下, 生産量を表 1 に, 出荷量 を表 2 に，平成18年度の探鉱および試掘関連の実績を表 3〜 5 に示した。

\subsection{2 世界の天然ガス}

\section{1. 世界の天然ガスの状況}

世界の天然ガス埋蔵量は, BP統計 (BP Statistical Review of World Energy, 2007) によれば，181.46 兆 $\mathrm{m}^{3}$ (6,404.48 兆立方

表 1 平成 18 年度天然ガス鉱床別生産量（平成 18 年 4 月 平成 19 年 3 月）

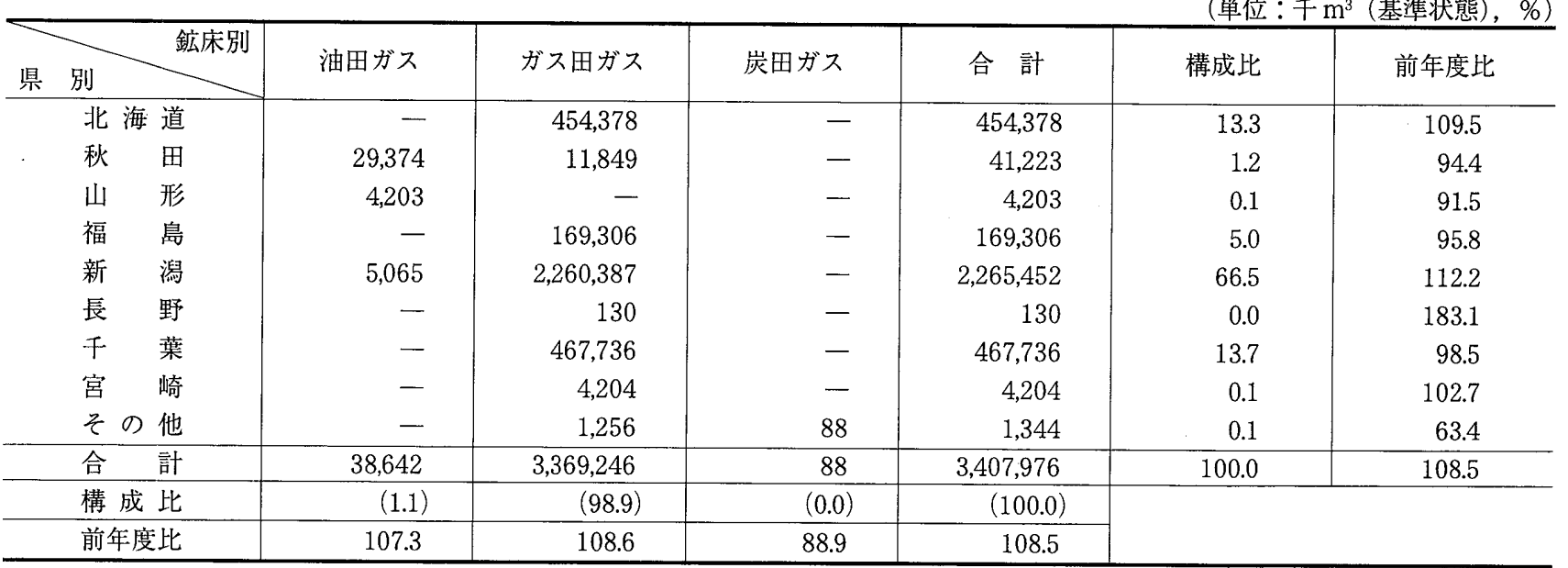

（資料）経済産業省「資源・エネルギー統計年報」

（注）東京，静岡の各県分はその他に含まれる。 